\title{
Ecological Health Risk Assessment of Heavy Metals in Farmland Soil of Changchun New Area
}

\author{
Qifa Sun ${ }^{1,3}$, Zhuoan Sun ${ }^{2 *}$, Weiguo Xing ${ }^{1}$, Guojie Hao ${ }^{1}$, Xuguang $\mathbf{L i}^{3}$, \\ Jizhong Du ${ }^{3}$, Chunhai Li ${ }^{1}$, Hui Tian ${ }^{3}$, Xiao $\mathrm{Li}^{3}$ \\ ${ }^{1}$ Harbin Natural Resources Comprehensive Investigation Center, CGS, Haerbin 150081, P.R. China \\ ${ }^{2}$ Shenyang Laboratory of National Gemstone Testing Center, Shenyang 110034, P.R. China \\ ${ }^{3}$ Shenyang Center of Geological Survey, CGS, Shenyang 110034, P.R. China
}

Received: 28 January 2021

Accepted: 8 April 2021

\begin{abstract}
In order to understand the status of soil heavy metal pollution and its impact on human health, the degree of soil heavy metal pollution in the Changchun New Area and the associated ecological risk and health risk were evaluated using the geo-accumulation index method, potential ecological risk index method, and health risk assessment model. The results showed that the average contents of eight heavy metals in the soil were higher than their background values in Changchun City, with different degrees of accumulation. The soil of Changchun New Area showed $\mathrm{Hg}$ and $\mathrm{Cd}$ pollution, with ecological risks. The average geo-accumulation index of $\mathrm{Hg}$ was 0.43 , reflecting light to medium pollution, and the risk index ranged from 42 to 806 , reflecting moderate to strong ecological risk. The level of Cd pollution was found to be light. In contrast, the soil was free of $\mathrm{Cr}, \mathrm{Ni}, \mathrm{Pb}, \mathrm{Zn}, \mathrm{As}$, and $\mathrm{Cu}$ pollution, with no apparent risk. However, they all exceeded the reference value of soil treatment proposed by the United States Environmental Protection Agency $\left(10^{-6}\right)$. Therefore, prevention measures for heavy metal pollution should be further strengthened.
\end{abstract}

Keywords: farmland soil, heavy metal, ecological risk, health risk, China

\section{Introduction}

Soil is one of the most precious natural resources. Healthy soil is a prerequisite for agricultural production and human survival. With the progress of industrialization, the soil ecological environment is continuously deteriorating, and the problem of soil pollution is becoming increasingly serious. In particular, heavy metal pollution in farmland soil is concerning

*e-mail: 1144746765@qq.com

because it will affect food quality and food safety, and endanger human health [1]. Areas surrounding mining areas and urban areas are high-risk areas for soil heavy metal pollution. Heavy metals enter the soil through the diffusion or leaching of dust, residual tailings, slag, and waste rock generated by mining, stacking, and transportation activities. In recent years, the problem of heavy metal pollution in farmland soil has extensively attracted the attention of domestic and international scholars.

Diami S. et al. [2] evaluated the ecological risk and human health risk of heavy metals in the surface soil 
of an iron mine area in Malaysia, and found that $\mathrm{Cd}$, $\mathrm{Pb}, \mathrm{As}$, and $\mathrm{Cu}$ exhibited low ecological risk, without any non-carcinogenic risk, but As exhibited high potential carcinogenic risk. Obiora S.C. et al. [3] studied the degree of heavy metal pollution in cultivated land around a zinc mining area in Southeast Nigeria, and reported over standard rates of $\mathrm{Pb}$ and $\mathrm{Zn}$ to be $87 \%$ and $31 \%$, respectively. Nihal G. et al. [4] evaluated the degree of soil pollution, and potential ecological and health risks of MSW disposal near Ramsar area, Assam state, India, and found that zinc was significantly enriched, manganese was slightly to moderately enriched, and chromium intake posed a serious threat to human health. Enkhxhimeg B. et al. [5] evaluated the human health and potential ecological risks of soil heavy metal pollution in the ger district of Ulaanbaatar City, Mongolia, and found that soil heavy metal pollution was relatively high. The ecological risk of chromium and arsenic is higher than that of other heavy metals. Wang X.M. et al. [6] studied heavy metals in farmland soil around a coal mine in Huainan, and found that the concentrations of $\mathrm{Pb}, \mathrm{Cd}, \mathrm{Zn}$, and $\mathrm{Cu}$ in the soil were significantly higher than their background values in Huainan, reflecting a mild to moderate risk level. Jiang H.H. et al. [7] evaluated the ecological and human health risks of heavy metals in soil. The results showed that industrial activities are the largest contributor ecological risk, and agricultural production is the largest contributor to human health risk. Heavy metals in farmland soil have adverse effects on the ecology and human health. Cao Q. et al. [8] analyzed the distribution characteristics and harmfulness of heavy metals in vegetable soil in greenhouse with time. The contents of $\mathrm{Ni}, \mathrm{Cu}, \mathrm{Zn}, \mathrm{Cd}$, and $\mathrm{Pb}$ in greenhouse vegetable soils (GVS) reached peak values over a period of 6-10 years or 11-15 years, reflecting high metal accumulation. In addition, the concentration of $\mathrm{Cr}$ in GVS over the first decade was significantly higher than that in the second decade, which may be related to its bioaccumulation and leaching. Tian M.L. et al. [9] assessed As, Cd, Sb, Pb, $\mathrm{Zn}$, and $\mathrm{Cu}$ pollution in paddy soil in an area affected by mining activities in Nandan, Guangxi, and found that $\mathrm{Cd}$ and As were seriously exceeded the standards.

The Changchun New Area is the $17^{\text {th }}$ national level new area approved by the State Council on February 3, 2016. It is located in Changchun City, Jilin Province, including Shuangde township of Chaoyang District, Fenjin township of Kuancheng District, Longjia town of Erdao District, and Xiyingcheng street of Jiutai District. It is a modern new area integrating economic development, green ecology and other elements. The law of heavy metal pollution in the Changchun New Area has been studied. Yang Z.P. et al. [10] evaluated heavy metals in the dust near the surface of Changchun City, mainly to assess potential health risks. Li H.J. et al. [11] analyzed the enrichment and transformation of heavy metals in the soil of coal mine wasteland by various plants. However, heavy metal pollution of farmland

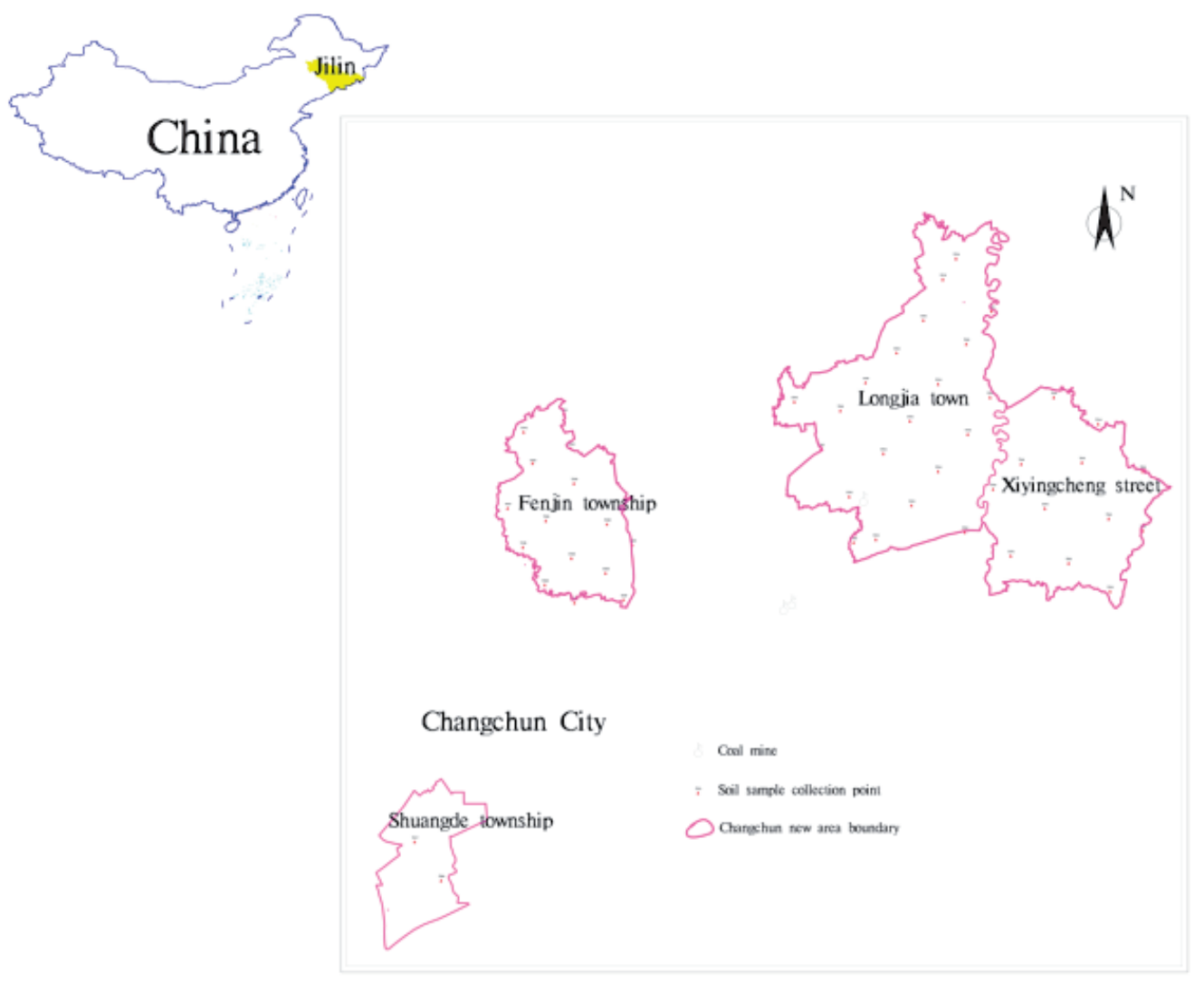

Fig. 1. Location map of sample collection points. 
soil over a wide range of the Changchun New Area has not been investigated thus far. Therefore, investigating heavy metals in farmland soil in the Changchun New Area is of high significance.

In this study, the pollution characteristics and ecological risk of heavy metals in farmland soil were systematically analyzed, and the human health risks of heavy metals were evaluated to establish a basis for scientific and reasonable prevention and control of farmland soil pollution, ecological environment protection, and ensuring healthy life of residents. The findings will contribute toward promoting the economic development of the economic circle and urban agglomeration and the comprehensive revitalization of the old northeast industrial base.

\section{Materials and Methods}

\section{Sample Collection and Testing}

In the study area, surface soil samples were collected from cultivated land or garden land using the grid sampling method, with a sampling density of $0.47 / \mathrm{km}^{2}$. Taking the GPS positioning sampling point as the center, 3-5 sampling points were selected by radiating $30-50 \mathrm{~m}$ around. In the sampling process, 0-20 cm surface soil samples were directly collected using a wooden shovel, avoiding uneven and unrepresentative sections, such as ditches, ridges, roadsides, forest belts, and old house foundations. The soil was broken up at each sample separation point. After removing plant root system, straw, stones, and other sundries, the soil was fully mixed and stored in $1.0-1.5 \mathrm{~kg}$ bags. The soil samples were dried, crushed, and sent to the laboratory for testing after passing through a 20 mesh nylon sieve. Samples of equal weights $\left(1.41-2.35 \mathrm{~km}^{2}\right)$ within a large grid were combined into one analysis sample. In total, 230 single point samples of surface soil and 50 combined analysis samples were collected from within the entire study area. Fig. 1 shows the distribution of sites from which the combined analysis samples were collected.

Sample testing was performed at the Northeast Mineral Resources Supervision and Testing Center of the Ministry of Land and Resources in accordance with the technical requirements for analysis of samples for eco geochemical evaluation (DD 2005-03)[12]. The analysis indices, determination methods, and detection limits are shown in Table 1. The accuracy and precision were controlled by national first-class reference materials, and the qualification rate of element analysis accuracy and precision was higher than 98\%; the reporting rate of element analysis was higher than $99.6 \%$.

\section{Evaluation Method}

\section{Evaluation of Heavy Metal Pollution in Soil}

The land accumulation index method proposed by German scientist Muller G [13] was adopted to evaluate the degree of soil heavy metal pollution. The calculation formula is as follows:

$$
I_{g e o}=\log _{2}\left[\frac{\mathrm{C}_{i}}{\mathrm{k} \times \mathrm{S}_{i}}\right]
$$

...where $I_{\text {geo }}$ represents the geo-accumulation index of heavy metal $\mathrm{i} ; \mathrm{C}_{i}$ represents the actual measured value of heavy metal $\mathrm{i}$ in soil; $\mathrm{Si}$ represents the reference value; $\mathrm{k}$ is the correction coefficient, generally 1.5 . The background value of heavy metal elements in the soil of Changchun City (obtained from the statistics of 1:250000 land quality geochemical survey data of Changchun City) was set as the reference value. The assessment grade of heavy metal pollution was divided according to the cumulative index of $I_{\text {geo }}$ [14] (Table 2).

\section{Ecological Risk Assessment of Heavy Metals in Soil}

Hakanson's potential ecological hazard index method was used to evaluate the ecological risk of heavy metals in the soil of the study area. This method not only refers to the material content of heavy metals, but also relates to the ecological, environmental, and toxicological effects of heavy metals. It is widely used in ecological risk assessment at present [15-17]. The calculation formula is as follows:

Table 1. Element analysis method and detection limit $\left(\mathrm{mg} \cdot \mathrm{kg}^{-1}\right)$.

\begin{tabular}{|c|c|c|c|c|c|}
\hline Index & Determination method & Detection limit & Index & Determination method & Detection limit \\
\hline $\mathrm{Cr}$ & \multirow{3}{*}{$\mathrm{X}$ ray fluorescence spectrometry } & 3 & $\mathrm{Cu}$ & \multirow{3}{*}{ Plasma emission spectrometry } & 1 \\
\hline $\mathrm{Pb}$ & & 2 & $\mathrm{Ni}$ & & 1 \\
\hline $\mathrm{Zn}$ & & 1 & $\mathrm{Mn}$ & & 10 \\
\hline As & \multirow{2}{*}{ Atomic fluorescence spectrometry } & 0.2 & $\mathrm{Cd}$ & Plasma mass spectrometry & 0.02 \\
\hline $\mathrm{Hg}$ & & 0.0005 & $\mathrm{pH}$ & PH meter electrode method & 0.10 \\
\hline
\end{tabular}

Note: $\mathrm{pH}$ is dimensionless 
Table 2. $\mathrm{I}_{\text {geo }}$ index and the criteria of pollution grade.

\begin{tabular}{|c|c|c|}
\hline $\begin{array}{c}\text { Land accumulation } \\
\text { index } I_{g e o}\end{array}$ & Level & Pollution degree \\
\hline$I_{g e o}<0$ & 0 & Pollution-free \\
\hline $0 \leq I_{g e o}<1$ & 1 & Light pollution \\
\hline $1 \leq I_{g e o}<2$ & 2 & Medium pollution \\
\hline $2 \leq I_{g e o}<3$ & 3 & Medium to heavy pollution \\
\hline $3 \leq I_{\text {geo }}<4$ & 4 & Heavy pollution \\
\hline $4 \leq I_{g e o}<5$ & 5 & $\begin{array}{c}\text { Heavy to extremely heavy } \\
\text { pollution }\end{array}$ \\
\hline $5 \leq I_{\text {geo }}$ & 6 & Extremely heavy pollution \\
\hline
\end{tabular}

$$
R I=\sum_{i=1}^{n} E_{r}^{i}=\sum_{i=1}^{n}\left(T_{r}^{i} \times C_{f}^{i}\right)=\sum_{i=1}^{n}\left(T_{r}^{i} \times \frac{C_{i}}{C_{n}^{i}}\right)
$$

...where $C_{f}^{i}$ is the pollution index of a metal; $C_{i}$ is the measured value of a heavy metal in soil; $C_{n}{ }^{i}$ is the reference value of a certain heavy metal (background value of heavy metal in Changchun soil); $E_{r}{ }^{i}$ is the potential ecological risk index of a single heavy metal; $T_{r}^{i}$ is the toxicity response parameter of a heavy metal; $R I$ is the total potential ecological risk index. The Toxicity Coefficient of each heavy metal is as follows: $\mathrm{Zn}=<\mathrm{CR}=\mathrm{Mn}=2<\mathrm{Cu}=\mathrm{Ni}=\mathrm{Pb}=5<\mathrm{As}=10<$ $\mathrm{Cd}=30<\mathrm{Hg}=40$ [18-19]. Single factor potential ecological hazards and total potential ecological hazards were classified according to $E_{r}^{i}$ and $R I$ (Table 3).

\section{Human Health Risk Assessment of Heavy Metals in Soil}

The health risk assessment model published by USEPA was used to assess human health risks. The assessment steps included exposure calculation and risk characterization. Soil heavy metals are absorbed by humans through plants in three ways: oral direct intake, respiratory inhalation, and skin contact, which pose non-carcinogenic and carcinogenic risks to human health. These risks were characterized in this study.

(1) Exposure calculation

The daily average carcinogenic and noncarcinogenic heavy metal exposure pathways were calculated as follows:

$$
A D D_{i \mathrm{ing}}=\frac{C_{i} \times \operatorname{IngR} \times E F \times E D}{B W \times A T} \times 10^{-6}
$$

$$
\begin{gathered}
A D D_{i \mathrm{inh}}=\frac{C i \times \operatorname{InhR} \times E F \times E D}{P E F \times B W \times A T} \\
A D D_{i \mathrm{derm}}=\frac{C_{i} \times S A \times S L \times A B S \times E F \times E D}{B W \times A T} \times 10^{-6}
\end{gathered}
$$

...where $A D D_{\text {ing }}, A D D_{i \text { inhh }}$, and $A D D_{i \text { derm }}$ represent the daily average exposure of a heavy metal through oral intake, respiratory intake, and skin contact, respectively, and CI represents the concentration of a heavy metal pollutant in soil. The exposed skin area was calculated according to the exposed skin area of Chinese people in different seasons and the climate characteristics of Changchun City according to Mielczarek A. et al. [20]. Other parameters were referred from HJ 25.3-2014 [21] and human parameters issued by the US EPA [22] (Table 4).

The average daily exposure of carcinogenic heavy metals in children is different from that in adults. It is necessary to calculate the exposure of children and adults separately, then weight the average, and finally allocate the exposure to the entire life cycle. The calculation formula is as follows:

$L A D D_{\text {iing }}=\frac{C_{i} \times E F}{A T}\left(\frac{\operatorname{Ing} R_{\text {child }} \times E D_{\text {child }}}{B W_{\text {child }}}+\frac{\operatorname{Ing} R_{\text {adult }} \times E D_{\text {adult }}}{B W_{\text {adult }}}\right) \times 10^{-6}$

$L A D D_{\text {inh }}=\frac{C_{i} \times E F}{P E F \times A T} \times\left(\frac{I n h R_{\text {child }} \times E D_{\text {child }}}{B W_{\text {child }}}+\frac{I n h R_{\text {adult }} \times E D_{\text {adult }}}{B W_{\text {adult }}}\right)$

$L A D D_{\text {iderm }}=\frac{C i \times E F \times S L \times A B S}{A T} \times\left(\frac{S A_{\text {child }} \times E D_{\text {child }}}{B W_{\text {child }}}+\frac{S A_{\text {adult }} \times E D_{\text {adult }}}{B W_{\text {adult }}}\right) \times 10^{-6}$

(2) Risk characterization

$$
H Q=\sum H Q_{i}=\sum \frac{A D D_{i \mathrm{ing}}+A D D_{i \mathrm{inh}}+A D D_{i \mathrm{derm}}}{R f D_{i}}
$$

$C R=\sum C R_{i}=\sum\left(A D D_{i \mathrm{ing}}+A D D_{i \mathrm{inh}}+A D D_{i \mathrm{derm}}\right) \times S F$

In the formula, $H Q$ refers to the non-carcinogenic risk index of all heavy metals; $H Q_{i}$ refers to the noncarcinogenic risk index of a single heavy metal I; $R f D_{i}$ refers to the non-carcinogenic daily average intake of heavy metal i. $H Q$ or $H Q_{i}<1$ indicates that the noncarcinogenic risk can be ignored, otherwise, the non-

Table 3. Indices used to assess the potential ecological risk status.

\begin{tabular}{|c|c|c|c|c|c|}
\hline Ecological hazards & Slight & Medium & Strong & Very strong & Extremely strong \\
\hline Potential ecological hazard index of single heavy metal $E_{r}^{i}$ & $<40$ & $40-80$ & $80-160$ & $160-320$ & $\geq 320$ \\
\hline Total potential ecological hazard index $R I$ & $<150$ & $150-300$ & $300-600$ & $600-1200$ & $\geq 1200$ \\
\hline
\end{tabular}


Table 4. Health risk exposure parameters of heavy metals.

\begin{tabular}{|c|c|c|c|c|}
\hline Symbol & Parameter & Unit & Adult reference value & Child reference value \\
\hline ED & Exposure years & $\mathrm{a}$ & 25 & 6 \\
\hline BW & Average weight & $\mathrm{kg}$ & 56.8 & 15.9 \\
\hline $\mathrm{EF}$ & Exposure frequency & $d \cdot a^{-1}$ & 350 & 350 \\
\hline AT & Average exposure time & d & $\begin{array}{c}\text { Carcinogenic26280, } \\
\text { noncarcinogenic } 9125\end{array}$ & $\begin{array}{c}\text { Carcinogenic26280, } \\
\text { noncarcinogenic2190 }\end{array}$ \\
\hline IngR & Daily soil intake & $\mathrm{mg} \cdot \mathrm{d}^{-1}$ & 100 & 200 \\
\hline InhR & Daily air respiration & $\mathrm{m}^{3} \cdot \mathrm{d}^{-1}$ & 14.5 & 7.5 \\
\hline SA & Exposed skin surface area & $\mathrm{cm}^{2}$ & 2415 & 1295 \\
\hline SL & Skin adhesion coefficient & $\mathrm{mg}\left(\mathrm{cm}^{2} \cdot \mathrm{d}\right)^{-1}$ & 0.2 & 0.2 \\
\hline PEF & Surface dust emission factor & $\mathrm{m}^{3} \cdot \mathrm{kg}^{-1}$ & $1.36 \times 10^{9}$ & $1.36 \times 10^{9}$ \\
\hline ABS & Skin absorption factor & & 0.001 & 0.001 \\
\hline
\end{tabular}

carcinogenic risk cannot be ignored. $C R$ refers to the carcinogenic health risk index of all heavy metals, $C R_{i}$ refers to the carcinogenic risk index of single heavy metal I, and SF refers to the carcinogenic slope factor. The $R f D$ and $S F$ values of different exposure routes are shown in Table 5 [23-26]. According to some studies, the acceptable range of the carcinogenic health risk index $C R$ or $C R_{i}$ is $10^{-6}-10^{-4}$ [27-28] .

\section{Results and Discussion}

\section{Distribution Characteristics of Heavy Metals in Soil}

The heavy metal content of farmland soil in the study area (Table 6) followed the order $\mathrm{Zn}>\mathrm{Cr}>\mathrm{Ni}>$ $\mathrm{Pb}>\mathrm{Cu}>\mathrm{As}>\mathrm{Cd}>\mathrm{Hg}$, with values exceeding the background level of Changchun City except for $\mathrm{Pb}$. This shows that most heavy metals accumulate in the soil to a certain extent. Specifically, $\mathrm{Hg}$ content was $0.019-0.363 \mathrm{mg} \cdot \mathrm{kg}^{-1}$ with an average value of $0.05 \mathrm{mg} \cdot \mathrm{kg}^{-1}$, which is more than 2.78 times that of the background value of Changchun soil; the average value of $\mathrm{Cd}$ content was $0.15 \mathrm{mg} \cdot \mathrm{kg}^{-1}$, which is 1.88 times that of the background value; $\mathrm{Ni}, \mathrm{Cr}, \mathrm{Zn}, \mathrm{As}$, and $\mathrm{Cu}$ contents were approximately 1-1.5 those of their background values. $\mathrm{Hg}$ exhibited the most prominent accumulation, followed by $\mathrm{Cd}$, and then $\mathrm{Ni}, \mathrm{Cr}, \mathrm{Zn}$, $\mathrm{As}$, and $\mathrm{Cu}$. The coefficient of variation was used to characterize the distribution of elements in soil. $\mathrm{Hg}$ exhibited a significantly higher coefficient of variation than other elements, reaching 1.136; the coefficient of variation of $\mathrm{Cd}$ was also high at 0.035 , while those of the other six elements ranged from 0.097 to 0.178 . If the coefficient of variation is small, the distribution of elements will be uniform. If the coefficient of variation is large, the distribution of elements will be more uneven and the impact of human activities would be stronger. In the study area, $\mathrm{Hg}$ is the most affected by human activities.

Table 5. Heavy metal reference measurement and carcinogenic slope factor.

\begin{tabular}{|c|c|c|c|c|c|c|}
\hline \multirow{2}{*}{ Heavy metal } & \multicolumn{2}{|c|}{ Reference measurement RfD $\left(\mathrm{mg} \cdot \mathrm{kg}^{-1} \cdot \mathrm{d}^{-1}\right)$} & \multicolumn{3}{c|}{ Carcinogen SF $\left(\mathrm{kg} \cdot \mathrm{d} \cdot \mathrm{mg}^{-1}\right)$} \\
\cline { 2 - 7 } & Through mouth & Skin & Breathing & Through mouth & Skin & Breathing \\
\hline $\mathrm{As}$ & $3.0 \times 10^{-4}$ & $3.0 \times 10^{-4}$ & $1.5 \times 10^{-5}$ & 1.5 & 6.1 & $4.3 \times 10^{-3}$ \\
\hline $\mathrm{Cd}$ & $1.0 \times 10^{-3}$ & $2.5 \times 10^{-5}$ & $1.0 \times 10^{-5}$ & 6.1 & -6.3 \\
\hline $\mathrm{Cr}$ & $3.0 \times 10^{-3}$ & $7.5 \times 10^{-5}$ & $2.55 \times 10^{-5}$ & - & - & 42 \\
\hline $\mathrm{Cu}$ & $4.0 \times 10^{-2}$ & $4.0 \times 10^{-2}$ & - & - & - & - \\
\hline $\mathrm{Hg}$ & $3.0 \times 10^{-4}$ & $2.1 \times 10^{-5}$ & $3.0 \times 10^{-4}$ & - & - & 0.84 \\
\hline $\mathrm{Ni}$ & $2.0 \times 10^{-2}$ & $8.0 \times 10^{-4}$ & $2.3 \times 10^{-5}$ & - & - & - \\
\hline $\mathrm{Pb}$ & $3.5 \times 10^{-3}$ & $5.3 \times 10^{-4}$ & $3.5 \times 10^{-3}$ & - & - & - \\
\hline $\mathrm{Zn}$ & $3.0 \times 10^{-1}$ & $3.0 \times 10^{-1}$ & - & - & - & - \\
\hline
\end{tabular}


Table 6. Characteristic value of heavy metal content in surface soil of the study area.

\begin{tabular}{|c|c|c|c|c|c|c|c|c|c|}
\hline \multicolumn{2}{|c|}{ Characteristic parameter } & As & $\mathrm{Cd}$ & $\mathrm{Cr}$ & $\mathrm{Cu}$ & $\mathrm{Hg}$ & $\mathrm{Ni}$ & $\mathrm{Pb}$ & $\mathrm{Zn}$ \\
\hline \multicolumn{2}{|c|}{ Minimum value } & 7 & 0.06 & 45 & 15 & 0.019 & 16 & 21 & 48 \\
\hline \multicolumn{2}{|c|}{ Maximum value } & 19 & 0.33 & 77 & 31 & 0.363 & 39 & 32 & 120 \\
\hline \multicolumn{2}{|c|}{ Average value } & 11.6 & 0.15 & 65.2 & 23.6 & 0.05 & 29.9 & 25.9 & 70.9 \\
\hline \multicolumn{2}{|c|}{ Coefficient of variation } & 0.18 & 0.36 & 0.11 & 0.13 & 1.14 & 0.16 & 0.10 & 0.16 \\
\hline \multicolumn{2}{|c|}{ Changchun soil background value } & 11 & 0.08 & 64 & 22 & 0.02 & 28 & 27 & 63 \\
\hline \multirow{4}{*}{$\begin{array}{c}\text { Risk screening value } \\
\text { of agricultural soil } \\
\text { pollution }\end{array}$} & $\mathrm{pH} \leq 5.5$ & 30 & 0.3 & 150 & 50 & 0.5 & 60 & 70 & 200 \\
\hline & $5.5-6.5$ & 30 & 0.3 & 150 & 50 & 0.5 & 70 & 90 & 200 \\
\hline & $6.5-7.5$ & 25 & 0.3 & 200 & 100 & 0.6 & 100 & 120 & 250 \\
\hline & $\mathrm{pH}>7.5$ & 20 & 0.6 & 250 & 100 & 1 & 190 & 170 & 300 \\
\hline
\end{tabular}

Note: The background value of heavy metals in the soil of Changchun City was obtained from the geochemical survey data of land quality [29], and the Changchun New Area is within this range; the coefficient of variation is dimensionless.

The $\mathrm{pH}$ value of soil in the study area ranged from 4.5 to 7.9. The distribution characteristics of different heavy metals are shown in Fig. 2. As, $\mathrm{Cu}, \mathrm{Pb}, \mathrm{Cr}, \mathrm{Ni}, \mathrm{Hg}$, and $\mathrm{Zn}$ did not exceed the standard compared with the screening value of soil pollution risk of agricultural land [30], except for one sample with Cd exceeding the
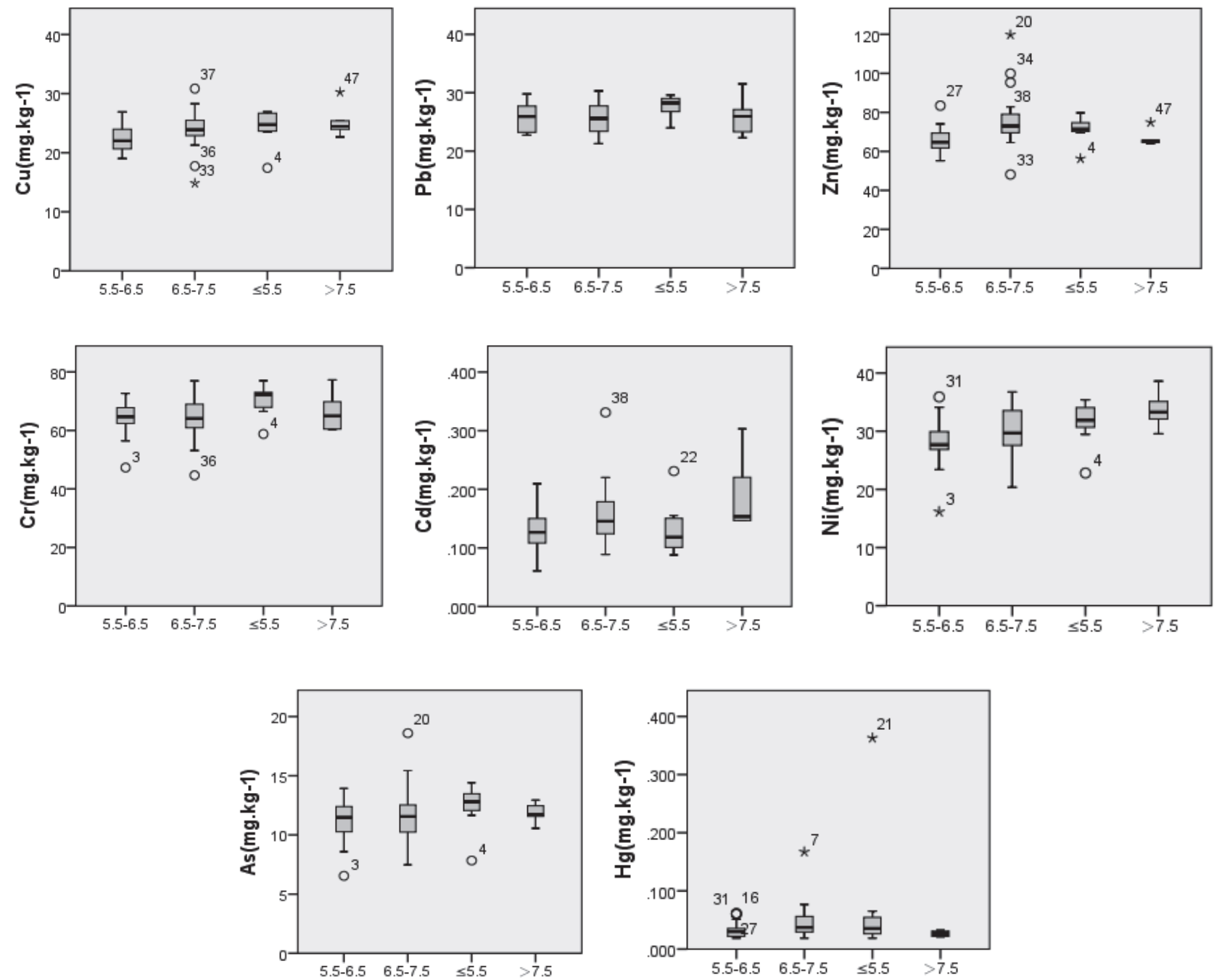

Fig. 2. Box plot of heavy metal concentration. 
Table 7. Classification of heavy metals in soil based on $\mathrm{I}_{\mathrm{gec}}$

\begin{tabular}{|c|c|c|c|c|c|c|c|c|}
\hline \multirow{2}{*}{$\begin{array}{l}\text { Heavy } \\
\text { metal }\end{array}$} & \multirow{2}{*}{$\begin{array}{l}\text { Index } \\
\text { mean }\end{array}$} & \multicolumn{7}{|c|}{ Number of samples at all levels } \\
\hline & & $\begin{array}{l}\text { Pollution- } \\
\text { free }\end{array}$ & $\begin{array}{c}\text { Light } \\
\text { pollution }\end{array}$ & $\begin{array}{l}\text { Medium } \\
\text { pollution }\end{array}$ & $\begin{array}{c}\text { Medium to } \\
\text { heavy pollution }\end{array}$ & $\begin{array}{c}\text { Heavy } \\
\text { pollution }\end{array}$ & $\begin{array}{l}\text { Heavy to extremely } \\
\text { heavy pollution }\end{array}$ & $\begin{array}{c}\text { Extremely } \\
\text { heavy pollution }\end{array}$ \\
\hline As & -0.53 & 49 & 1 & 0 & 0 & 0 & 0 & 0 \\
\hline $\mathrm{Cd}$ & 0.223 & 16 & 32 & 2 & 0 & 0 & 0 & 0 \\
\hline $\mathrm{Cr}$ & -0.567 & 50 & 0 & 0 & 0 & 0 & 0 & 0 \\
\hline $\mathrm{Cu}$ & -0.498 & 50 & 0 & 0 & 0 & 0 & 0 & 0 \\
\hline $\mathrm{Hg}$ & 0.425 & 17 & 22 & 9 & 1 & 1 & 0 & 0 \\
\hline $\mathrm{Ni}$ & -0.509 & 50 & 0 & 0 & 0 & 0 & 0 & 0 \\
\hline $\mathrm{Pb}$ & -0.651 & 50 & 0 & 0 & 0 & 0 & 0 & 0 \\
\hline $\mathrm{Zn}$ & -0.431 & 47 & 3 & 0 & 0 & 0 & 0 & 0 \\
\hline
\end{tabular}

standard. Cd appeared as the main element exceeding the standard. Therefore, it may pose serious risks to the ecology, environment, and human health in the study area.

\section{Analysis of Heavy Metal Pollution Degree}

Taking the background values of soil elements in Changchun City as the evaluation standard, the degree of heavy metal pollution in the soil of the study area was evaluated using the geo-accumulation index method (Table 7). The average heavy metal pollution index of the considered elements followed the order: $\mathrm{As}<\mathrm{Pb}<\mathrm{Cr}<\mathrm{Ni}<\mathrm{Cu}<\mathrm{Zn}<\mathrm{Cd}<\mathrm{Hg}$. Hg pollution appeared to be the most serious, with light to medium levels accounting for $44 \%$ and $18 \%$ of the total samples, one medium to heavy pollution point accounting for $2 \%$, and one heavy pollution point accounting for $2 \%$. The land accumulation index of $\mathrm{Cd}$ was between 0 and 1 , representing a light pollution level. Two samples showed medium pollution levels. The cumulative indices of $\mathrm{Cr}$,
$\mathrm{Ni}, \mathrm{Pb}, \mathrm{Zn}, \mathrm{As}$, and $\mathrm{Cu}$ were all less than 1 , reflecting pollution-free soil. Overall, in the Changchun New Area, $\mathrm{Hg}$ pollution is relatively prominent, with serious levels, and wider distribution, followed by $\mathrm{Cd}$.

\section{Potential Ecological Risk Assessment of Heavy Metals}

The degree of potential ecological risks of heavy metals in the soil of the Changchun New Area was evaluated using the soil background values of Changchun as the reference (Table 8). The ecological risk indices of $\mathrm{Ni}, \mathrm{Cr}, \mathrm{Pb}, \mathrm{As}, \mathrm{Zn}$, and $\mathrm{Cu}$ were less than 40, reflecting a slight ecological risk; the risk index of $\mathrm{Cd}$ ranged from 22.82 to 124.14 , reflecting slight to strong ecological risk - mainly medium risk accounting for $68 \%$ and strong risk accounting for $12 \%$. The risk index of $\mathrm{Hg}$ ranged from 41.56 to 806.33 , reflecting medium to strong ecological risk. $\mathrm{Hg}$ did not show the level of slight risk, and the proportion of medium, strong, very strong, and extremely strong risks were $64 \%, 30 \%, 2 \%$, and $4 \%$ respectively. Therefore, $\mathrm{Cd}$ and

Table 8. Potential ecological risk coefficient of heavy metals in soil.

\begin{tabular}{|c|c|c|c|c|c|c|c|}
\hline \multicolumn{2}{|c|}{ Hazard index } & \multirow{2}{*}{ Distribution range } & \multicolumn{5}{c|}{ Number of samples at all levels } \\
\cline { 4 - 8 } & & Slight & Medium & Strong & Very strong & Extremely strong \\
\hline \multirow{3}{*}{} & $\mathrm{As}$ & $5.95-16.9$ & 50 & 0 & 0 & 0 & 0 \\
\cline { 2 - 8 } & $\mathrm{Cd}$ & $22.82-124.14$ & 10 & 34 & 6 & 0 & 0 \\
\cline { 2 - 8 } & $\mathrm{Cr}$ & $1.4-2.41$ & 50 & 0 & 0 & 0 & 0 \\
\cline { 2 - 9 } & $\mathrm{Cu}$ & $3.37-7.01$ & 50 & 0 & 0 & 0 & 0 \\
\cline { 2 - 9 } & $\mathrm{Hg}$ & $41.56-806.33$ & 0 & 32 & 15 & 1 & 0 \\
\cline { 2 - 9 } & $\mathrm{Ni}$ & $2.88-6.89$ & 50 & 0 & 0 & 0 & 0 \\
\cline { 2 - 9 } & $\mathrm{Pb}$ & $3.94-5.83$ & 50 & 0 & 0 & 0 & 0 \\
\cline { 2 - 9 } & $\mathrm{Zn}$ & $0.76-1.9$ & 50 & 0 & 0 & 0 & 0 \\
\hline
\end{tabular}



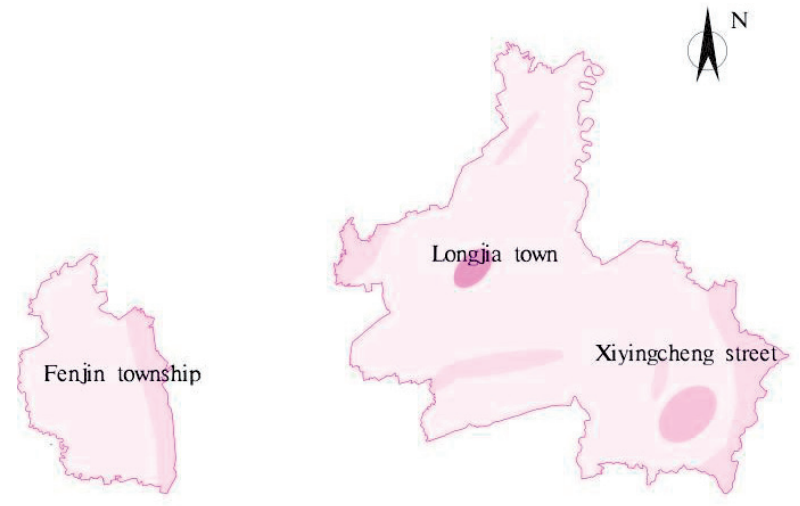

Changchun City

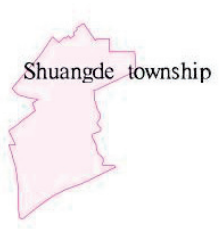

Fig. 3. Spatial distribution of total potential ecological grade.

$\mathrm{Hg}$ are the main elements in the soil of the study area posing serious ecological hazards.

The total potential ecological index, RI, of heavy metals in the Changchun New Area ranged from 94.64 to 893.97 , with slight to very strong ecological risks, mainly slight and moderate risks, accounting for $40 \%, 56 \%, 2 \%$, and $2 \%$, respectively. $\mathrm{Cd}$ and $\mathrm{Hg}$ appeared as influencing factors. The ecological risk of Hg was moderate, strong, very strong, and extremely strong. The ecological risk of $\mathrm{Cd}$ was slight, medium, and strong. In contrast, other heavy metals exhibited only slight ecological risk. According to the $R I$ spatial distribution map (Fig. 3), Longjia town has the highest ecological risk, with a large area of soil exhibiting extremely strong ecological risk. This area features large-scale coal mining enterprises integrating mining, washing and transportation activities, and $\mathrm{Hg}$ and $\mathrm{Cd}$ pollution of the soil near Longjia town can be attributed to the waste purchase station in this town. The eastern part of Fenjin Township and the eastern part of Xiying city have medium risk, while other areas have low risk.

\section{Human Health Risk Assessment}

\section{Heavy Metal Exposure Assessment Analysis}

In the assessment of heavy metal exposure, the daily exposure of heavy metals in the soil of the Changchun New Area was first evaluated (Table 9, Table 10). Regarding the non-carcinogenic average daily exposure, the average daily intake of adults and children followed the order: $A D D_{\text {ing }}>A D D_{\text {derm }}>A D D_{\text {inh }}$. The oral intake of heavy metals was much higher than that through skin contact and breathing. The average daily intake of three different heavy metals followed the order: $\mathrm{Hg}<\mathrm{Cd}<$ $\mathrm{Ni}<\mathrm{As}<\mathrm{Cu}<\mathrm{Pb}<\mathrm{Cr}<\mathrm{Zn}$. The daily intake and total daily intake of all heavy metals in adults were lower than those in children. In the average daily exposure of $\mathrm{Cd}$, $\mathrm{Ni}, \mathrm{Cr}$, and $\mathrm{As}$ in terms of carcinogenic risk, oral intake was also much higher than that of skin and respiration. The average daily intake followed the order $\mathrm{Cr}>\mathrm{Ni}$ $>\mathrm{As}>\mathrm{Cd}$. Therefore, through the assessment of noncarcinogenic and carcinogenic exposure of heavy metals in the soil of the Changchun New Area, oral intake can be ascertained to be the main exposure route, and the average daily exposure of adults is lower than that of children.

The non-carcinogenic and carcinogenic health risk indices of 8 heavy metals in the Changchun New Area were calculated according to the health risk assessment model, assessment parameters, and survey data (Table 11, Table 12).

According to the results of the non-carcinogenic health risk assessment, the non-carcinogenic risk of adults and children along different exposure routes for the same element followed the order $H Q_{\text {ing }}>H Q_{\text {derm }}$ $>H Q_{i n h}$. This is consistent with the conclusion of exposure assessment, indicating that the exposure pathway is related to non-carcinogenic risk, and the main pathway of non-carcinogenic risk is oral intake. The non-carcinogenic risk of different types of heavy metals followed the order $\mathrm{Hg}<\mathrm{Cd}<\mathrm{Zn}<\mathrm{Cu}<\mathrm{Ni}<\mathrm{Pb}<\mathrm{Cr}<\mathrm{As}$. The average value of the non-carcinogenic risk index of individual heavy metals was less than 1 , indicating that individual heavy metals do not pose carcinogenic risk to human health. The risk index of individual heavy metals in adults was lower than that in children, indicating that children are more likely to be vulnerable. 
Table 9. Average daily exposure to heavy metals in soil; non-carcinogenic risk assessment.

\begin{tabular}{|c|c|c|c|c|c|c|c|c|}
\hline \multirow{2}{*}{ Heavy metal } & \multicolumn{2}{|c}{$A D D_{\text {ing }}$} & \multicolumn{2}{c|}{$A D D_{\text {inh }}$} & \multicolumn{2}{c|}{$A D D_{\text {derm }}$} & \multicolumn{2}{c|}{ ADD } \\
\cline { 2 - 10 } & Adult & Children & Adult & Children & Adult & Children & Adult & Children \\
\hline $\mathrm{As}$ & $1.96 \mathrm{E}-05$ & $1.40 \mathrm{E}-04$ & $2.09 \mathrm{E}-09$ & $3.86 \mathrm{E}-09$ & $9.47 \mathrm{E}-08$ & $1.81 \mathrm{E}-07$ & $1.97 \mathrm{E}-05$ & $1.40 \mathrm{E}-04$ \\
\hline $\mathrm{Cd}$ & $2.50 \mathrm{E}-07$ & $1.79 \mathrm{E}-06$ & $2.67 \mathrm{E}-11$ & $4.93 \mathrm{E}-11$ & $1.21 \mathrm{E}-09$ & $2.31 \mathrm{E}-09$ & $2.51 \mathrm{E}-07$ & $1.79 \mathrm{E}-06$ \\
\hline $\mathrm{Cr}$ & $1.10 \mathrm{E}-04$ & $7.87 \mathrm{E}-04$ & $1.17 \mathrm{E}-08$ & $2.17 \mathrm{E}-08$ & $5.32 \mathrm{E}-07$ & $1.02 \mathrm{E}-06$ & $1.11 \mathrm{E}-04$ & $7.88 \mathrm{E}-04$ \\
\hline $\mathrm{Cu}$ & $3.98 \mathrm{E}-05$ & $2.84 \mathrm{E}-04$ & $4.24 \mathrm{E}-09$ & $7.84 \mathrm{E}-09$ & $1.92 \mathrm{E}-07$ & $3.68 \mathrm{E}-07$ & $4.00 \mathrm{E}-05$ & $2.85 \mathrm{E}-04$ \\
\hline $\mathrm{Hg}$ & $7.68 \mathrm{E}-08$ & $5.48 \mathrm{E}-07$ & $8.18 \mathrm{E}-12$ & $1.51 \mathrm{E}-11$ & $3.71 \mathrm{E}-10$ & $7.10 \mathrm{E}-10$ & $7.71 \mathrm{E}-08$ & $5.49 \mathrm{E}-07$ \\
\hline $\mathrm{Ni}$ & $1.75 \mathrm{E}-05$ & $4.76 \mathrm{E}-05$ & $1.87 \mathrm{E}-09$ & $2.70 \mathrm{E}-09$ & $8.47 \mathrm{E}-08$ & $1.24 \mathrm{E}-07$ & $1.76 \mathrm{E}-05$ & $4.77 \mathrm{E}-05$ \\
\hline $\mathrm{Pb}$ & $4.37 \mathrm{E}-05$ & $3.13 \mathrm{E}-04$ & $4.66 \mathrm{E}-09$ & $8.62 \mathrm{E}-09$ & $2.11 \mathrm{E}-07$ & $4.05 \mathrm{E}-07$ & $4.40 \mathrm{E}-05$ & $3.13 \mathrm{E}-04$ \\
\hline $\mathrm{Zn}$ & $1.20 \mathrm{E}-04$ & $8.55 \mathrm{E}-04$ & $1.28 \mathrm{E}-08$ & $2.36 \mathrm{E}-08$ & $5.78 \mathrm{E}-07$ & $1.11 \mathrm{E}-06$ & $1.20 \mathrm{E}-04$ & $8.57 \mathrm{E}-04$ \\
\hline $\mathrm{ADD}$ & $3.84 \mathrm{E}-04$ & $2.74 \mathrm{E}-03$ & $4.09 \mathrm{E}-08$ & $7.56 \mathrm{E}-08$ & $1.85 \mathrm{E}-06$ & $3.55 \mathrm{E}-06$ & $3.86 \mathrm{E}-04$ & $2.75 \mathrm{E}-03$ \\
\hline
\end{tabular}

Table 10. Average daily exposure to heavy metals in soil; carcinogenic risk assessment.

\begin{tabular}{|c|c|c|c|c|c|c|c|c|}
\hline \multirow{2}{*}{ Heavy metal } & \multicolumn{2}{|c|}{$A D D_{\text {ing }}$} & \multicolumn{2}{c|}{$A D D_{\text {inh }}$} & \multicolumn{2}{c|}{$A D D_{\text {derm }}$} & \multicolumn{2}{c|}{$A D D$} \\
\cline { 2 - 9 } & Adult & Children & Adult & Children & Adult & Children & Adult & Children \\
\hline As & $6.81 \mathrm{E}-06$ & $1.85 \mathrm{E}-05$ & $7.26 \mathrm{E}-10$ & $1.05 \mathrm{E}-09$ & $3.29 \mathrm{E}-08$ & $4.80 \mathrm{E}-08$ & $6.84 \mathrm{E}-06$ & $1.85 \mathrm{E}-05$ \\
\hline $\mathrm{Cd}$ & $8.68 \mathrm{E}-08$ & $2.36 \mathrm{E}-07$ & $9.26 \mathrm{E}-12$ & $1.34 \mathrm{E}-11$ & $4.19 \mathrm{E}-10$ & $6.12 \mathrm{E}-10$ & $8.73 \mathrm{E}-08$ & $2.36 \mathrm{E}-07$ \\
\hline $\mathrm{Cr}$ & $3.82 \mathrm{E}-05$ & $1.04 \mathrm{E}-04$ & $4.08 \mathrm{E}-09$ & $5.88 \mathrm{E}-09$ & $1.85 \mathrm{E}-07$ & $2.70 \mathrm{E}-07$ & $3.84 \mathrm{E}-05$ & $1.04 \mathrm{E}-04$ \\
\hline $\mathrm{Ni}$ & $1.75 \mathrm{E}-05$ & $4.76 \mathrm{E}-05$ & $1.87 \mathrm{E}-09$ & $2.70 \mathrm{E}-09$ & $8.47 \mathrm{E}-08$ & $1.24 \mathrm{E}-07$ & $1.76 \mathrm{E}-05$ & $4.77 \mathrm{E}-05$ \\
\hline ADD & $6.27 \mathrm{E}-05$ & $1.70 \mathrm{E}-04$ & $6.68 \mathrm{E}-09$ & $9.64 \mathrm{E}-09$ & $3.03 \mathrm{E}-07$ & $4.42 \mathrm{E}-07$ & $6.30 \mathrm{E}-05$ & $1.71 \mathrm{E}-04$ \\
\hline
\end{tabular}

The average value of the non-carcinogenic health risk index for adults was 0.128 , and the maximum value was 0.182 , which indicates that the non-carcinogenic health risk of these eight elements in the soil of the Changchun New Area is small and negligible. The average value of the non-carcinogenic health risk index for children was 0.867 , and the maximum value was 1.24 , indicating that heavy metals pose non-carcinogenic health risk to children in this area (Fig. 4). As and $\mathrm{Cr}$ are the main non-carcinogenic elements in the soil of the Changchun New Area, posing the greatest threats to children. Therefore, special attention should be paid to the prevention and control of As and $\mathrm{Cr}$.

In the assessment of carcinogenic health risk, the same element along different exposure routes for adults and children followed the order $C R_{\text {ing }}>C R_{\text {derm }}>C R_{i n h}$, and the carcinogenic risk was closely related to the exposure route; the carcinogenic risk of heavy metals followed
Adult

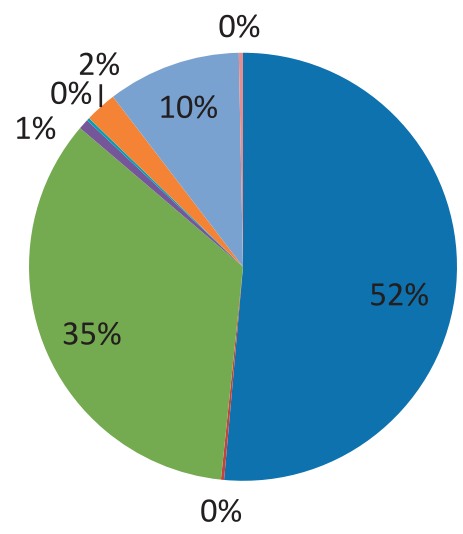

As

$\square \mathrm{Cd}$

$\mathrm{Cr}$

$\square \mathrm{Cu}$

$\square \mathrm{Hg}$

$\mathrm{Ni}$

$\mathrm{Pb}$

Zn
Children

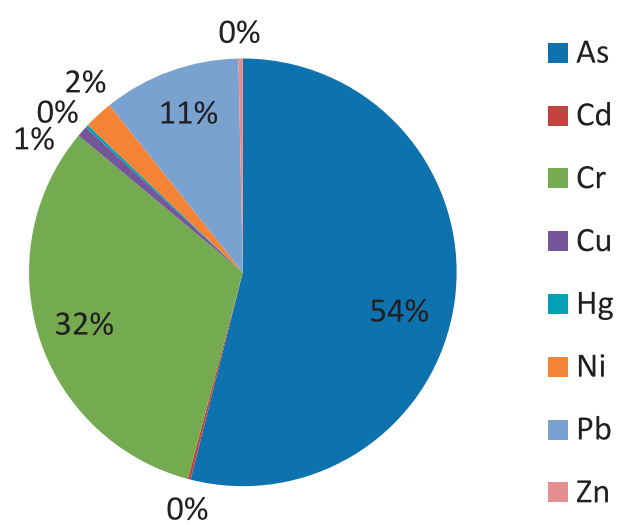

Fig. 4. Contribution of 8 heavy metals in the soil to $H Q$ for adults and children. 
Table 11. Non carcinogenic health risk index of heavy metals in soil in the Changchun New Area.

\begin{tabular}{|c|c|c|c|c|c|c|c|c|c|}
\hline \multirow{2}{*}{\multicolumn{2}{|c|}{ Heavy metal }} & \multicolumn{2}{|c|}{$H Q_{\text {ing }}$} & \multicolumn{2}{|c|}{$H Q_{i n h}$} & \multicolumn{2}{|c|}{$H Q_{\text {derm }}$} & \multicolumn{2}{|c|}{$H Q$} \\
\hline & & Adult & Children & Adult & Children & Adult & Children & Adult & Children \\
\hline \multirow{2}{*}{ As } & Max & $1.05 \mathrm{E}-01$ & 7.47E-01 & $2.23 \mathrm{E}-04$ & 4.12E-04 & $5.05 \mathrm{E}-04$ & $9.68 \mathrm{E}-04$ & $1.05 \mathrm{E}-01$ & 7.49E-01 \\
\hline & AVG & $6.53 \mathrm{E}-02$ & 4.67E-01 & $1.39 \mathrm{E}-04$ & $2.57 \mathrm{E}-04$ & $3.16 \mathrm{E}-04$ & $6.05 \mathrm{E}-04$ & $6.58 \mathrm{E}-02$ & $4.68 \mathrm{E}-01$ \\
\hline \multirow{2}{*}{$\mathrm{Cd}$} & Max & $5.59 \mathrm{E}-04$ & $3.99 \mathrm{E}-03$ & $5.96 \mathrm{E}-06$ & $1.10 \mathrm{E}-05$ & $1.08 \mathrm{E}-04$ & 2.07E-04 & $6.73 \mathrm{E}-04$ & $4.21 \mathrm{E}-03$ \\
\hline & AVG & $2.50 \mathrm{E}-04$ & $1.79 \mathrm{E}-03$ & $2.67 \mathrm{E}-06$ & 4.93E-06 & $4.83 \mathrm{E}-05$ & $9.26 \mathrm{E}-05$ & $3.01 \mathrm{E}-04$ & $1.88 \mathrm{E}-03$ \\
\hline \multirow{2}{*}{$\mathrm{Cr}$} & Max & $4.35 \mathrm{E}-02$ & $3.11 \mathrm{E}-01$ & $5.45 \mathrm{E}-04$ & $1.01 \mathrm{E}-03$ & $8.40 \mathrm{E}-03$ & $1.61 \mathrm{E}-02$ & $5.24 \mathrm{E}-02$ & $3.28 \mathrm{E}-01$ \\
\hline & AVG & $3.67 \mathrm{E}-02$ & $2.62 \mathrm{E}-01$ & $4.60 \mathrm{E}-04$ & $8.51 \mathrm{E}-04$ & 7.09E-03 & $1.36 \mathrm{E}-02$ & 4.42E-02 & 2.77E-01 \\
\hline \multirow{2}{*}{$\mathrm{Cu}$} & Max & $1.30 \mathrm{E}-03$ & $9.30 \mathrm{E}-03$ & - & - & $6.29 \mathrm{E}-06$ & $1.20 \mathrm{E}-05$ & $1.31 \mathrm{E}-03$ & $9.31 \mathrm{E}-03$ \\
\hline & AVG & $9.95 \mathrm{E}-04$ & 7.11E-03 & - & - & 4.81E-06 & $9.21 \mathrm{E}-06$ & $1.00 \mathrm{E}-03$ & 7.12E-03 \\
\hline \multirow{2}{*}{$\mathrm{Hg}$} & Max & $2.04 \mathrm{E}-03$ & $1.46 \mathrm{E}-02$ & $2.18 \mathrm{E}-07$ & 4.02E-07 & $1.41 \mathrm{E}-04$ & $2.70 \mathrm{E}-04$ & $2.18 \mathrm{E}-03$ & $1.49 \mathrm{E}-02$ \\
\hline & AVG & $2.56 \mathrm{E}-04$ & $1.83 \mathrm{E}-03$ & $2.73 \mathrm{E}-08$ & $5.04 \mathrm{E}-08$ & $1.77 \mathrm{E}-05$ & $3.38 \mathrm{E}-05$ & $2.74 \mathrm{E}-04$ & $1.86 \mathrm{E}-03$ \\
\hline \multirow{2}{*}{$\mathrm{Ni}$} & Max & $3.26 \mathrm{E}-03$ & $2.33 \mathrm{E}-02$ & $3.02 \mathrm{E}-04$ & $5.58 \mathrm{E}-04$ & 3.93E-04 & 7.54E-04 & $3.95 \mathrm{E}-03$ & $2.46 \mathrm{E}-02$ \\
\hline & AVG & $2.52 \mathrm{E}-03$ & $1.80 \mathrm{E}-02$ & $2.34 \mathrm{E}-04$ & 4.32E-04 & $3.05 \mathrm{E}-04$ & $5.84 \mathrm{E}-04$ & $3.06 \mathrm{E}-03$ & $1.91 \mathrm{E}-02$ \\
\hline \multirow{2}{*}{$\mathrm{Pb}$} & Max & $1.52 \mathrm{E}-02$ & $1.09 \mathrm{E}-01$ & $1.62 \mathrm{E}-06$ & $2.99 \mathrm{E}-06$ & $4.85 \mathrm{E}-04$ & $9.28 \mathrm{E}-04$ & $1.57 \mathrm{E}-02$ & $1.09 \mathrm{E}-01$ \\
\hline & AVG & $1.25 \mathrm{E}-02$ & 8.93E-02 & $1.33 \mathrm{E}-06$ & $2.46 \mathrm{E}-06$ & 3.99E-04 & 7.64E-04 & $1.29 \mathrm{E}-02$ & $9.01 \mathrm{E}-02$ \\
\hline \multirow{2}{*}{$\mathrm{Zn}$} & Max & $6.74 \mathrm{E}-04$ & $4.82 \mathrm{E}-03$ & - & - & $3.26 \mathrm{E}-06$ & $6.24 \mathrm{E}-06$ & $6.77 \mathrm{E}-04$ & $4.82 \mathrm{E}-03$ \\
\hline & AVG & $3.99 \mathrm{E}-04$ & $2.85 \mathrm{E}-03$ & - & - & $1.93 \mathrm{E}-06$ & $3.69 \mathrm{E}-06$ & $4.01 \mathrm{E}-04$ & $2.86 \mathrm{E}-03$ \\
\hline \multirow{2}{*}{ HQ } & Max & $1.71 \mathrm{E}-01$ & $1.22 \mathrm{E}+00$ & $1.08 \mathrm{E}-03$ & $1.99 \mathrm{E}-03$ & $1.00 \mathrm{E}-02$ & $1.92 \mathrm{E}-02$ & $1.82 \mathrm{E}-01$ & $1.24 \mathrm{E}+00$ \\
\hline & AVG & $1.19 \mathrm{E}-01$ & $8.50 \mathrm{E}-01$ & 8.38E-04 & $1.55 \mathrm{E}-03$ & $8.18 \mathrm{E}-03$ & $1.57 \mathrm{E}-02$ & $1.28 \mathrm{E}-01$ & 8.67E-01 \\
\hline
\end{tabular}

Note: Max-maximum value, AVG-average value.

Table 12. Carcinogenic health risk index of heavy metals in soil in the Changchun New Area.

\begin{tabular}{|c|c|c|c|c|c|c|c|c|c|}
\hline \multirow{2}{*}{\multicolumn{2}{|c|}{ Heavy metal }} & \multicolumn{2}{|c|}{$C R_{\text {ing }}$} & \multicolumn{2}{|c|}{$C R_{i n h}$} & \multicolumn{2}{|c|}{$C R_{\text {derm }}$} & \multicolumn{2}{|c|}{$C R$} \\
\hline & & Adult & Children & Adult & Children & Adult & Children & Adult & Children \\
\hline \multirow{2}{*}{ As } & Max & $1.63 \mathrm{E}-05$ & 4.44E-05 & $5.00 \mathrm{E}-12$ & $7.21 \mathrm{E}-12$ & 7.90E-08 & $1.15 \mathrm{E}-07$ & $1.64 \mathrm{E}-05$ & $4.45 \mathrm{E}-05$ \\
\hline & AVG & $1.02 \mathrm{E}-05$ & $2.77 \mathrm{E}-05$ & $3.12 \mathrm{E}-12$ & $4.50 \mathrm{E}-12$ & 4.93E-08 & $7.20 \mathrm{E}-08$ & $1.03 \mathrm{E}-05$ & $2.78 \mathrm{E}-05$ \\
\hline \multirow{2}{*}{$\mathrm{Cd}$} & Max & $1.18 \mathrm{E}-06$ & $3.21 \mathrm{E}-06$ & $1.30 \mathrm{E}-10$ & $1.88 \mathrm{E}-10$ & 5.72E-09 & $8.35 \mathrm{E}-09$ & $1.19 \mathrm{E}-06$ & $3.22 \mathrm{E}-06$ \\
\hline & AVG & $5.30 \mathrm{E}-07$ & $1.44 \mathrm{E}-06$ & $5.83 \mathrm{E}-11$ & $8.42 \mathrm{E}-11$ & $2.56 \mathrm{E}-09$ & $3.74 \mathrm{E}-09$ & $5.32 \mathrm{E}-07$ & $1.44 \mathrm{E}-06$ \\
\hline \multirow{2}{*}{$\mathrm{Cr}$} & Max & - & - & $2.03 \mathrm{E}-07$ & $2.93 \mathrm{E}-07$ & - & - & $2.03 \mathrm{E}-07$ & $2.93 \mathrm{E}-07$ \\
\hline & AVG & - & - & $1.71 \mathrm{E}-07$ & $2.47 \mathrm{E}-07$ & - & - & $1.71 \mathrm{E}-07$ & $2.47 \mathrm{E}-07$ \\
\hline \multirow{2}{*}{$\mathrm{Ni}$} & Max & - & - & 2.03E-09 & 2.93E-09 & - & - & 2.03E-09 & 2.93E-09 \\
\hline & AVG & - & - & $1.57 \mathrm{E}-09$ & 2.27E-09 & - & - & $1.57 \mathrm{E}-09$ & 2.27E-09 \\
\hline \multirow{2}{*}{$\mathrm{Cr}$} & Max & $1.75 \mathrm{E}-05$ & $4.76 \mathrm{E}-05$ & $2.05 \mathrm{E}-07$ & $2.96 \mathrm{E}-07$ & 8.47E-08 & $1.24 \mathrm{E}-07$ & $1.78 \mathrm{E}-05$ & $4.80 \mathrm{E}-05$ \\
\hline & AVG & $1.07 \mathrm{E}-05$ & $2.92 \mathrm{E}-05$ & $1.73 \mathrm{E}-07$ & $2.49 \mathrm{E}-07$ & 5.19E-08 & 7.57E-08 & $1.10 \mathrm{E}-05$ & $2.95 \mathrm{E}-05$ \\
\hline
\end{tabular}

Note: Max-maximum value, AVG-average value.

the order $\mathrm{As}>\mathrm{Cd}>\mathrm{Cr}>\mathrm{Ni}$, indicating that $\mathrm{As}$ has the highest carcinogenic risk. The average value of the total index of carcinogenic risk was $2.95 \times 10^{-5}$ and $1.1 \times 10^{-5}$ for children and adults, respectively. Values between $10^{-6}$ and $10^{-4}$ indicate a generally total carcinogenic risk, but they still exceed the benchmark value of soil treatment proposed by the US EPA $\left(10^{-6}\right)$. The maximum total index of carcinogenic risks for children and adults were 
$4.8 \times 10^{-5}$ and $1.78 \times 10^{-5}$, respectively. Values between $10^{-6}$ and $10^{-4}$ are generally believed to be acceptable, but they still exceed the benchmark value of soil treatment proposed by the US EPA $\left(10^{-6}\right)$. Therefore, the average and maximum values of the total index of carcinogenic risk for children and adults in this area exceed the benchmark values of soil governance proposed by the US EPA $\left(10^{-6}\right)$. Overall, the carcinogenic risk posed by heavy metals in the Changchun New Area is generally considered to be acceptable and will not significantly affect the health of local residents, but prevention measures for heavy metal pollution should be strengthened.

\section{Discussion}

Soil heavy metal pollution is one of the key problems in basic geological, environmental, and soil research. The results showed that the heavy metals $\mathrm{Hg}$, $\mathrm{Cd}$, As, and $\mathrm{Ni}$ in the farmland soil of the Changchun New Area reached heavy pollution level, medium pollution level, and light pollution level, whereas $\mathrm{Cr}, \mathrm{Hg}, \mathrm{Cu}, \mathrm{Ni}$, and $\mathrm{Zn}$ did not pollute the soil. Yang Z.P. et al. [31] found in 2015 that the average contents of $\mathrm{Cd}, \mathrm{Zn}, \mathrm{Cr}, \mathrm{Hg}, \mathrm{Cu}, \mathrm{Pb}$, and As in surface dust of Changchun City were significantly higher than those of heavy metals in surface soil of the study area, with a wide variation range. In 2005, Guo P. et al. [32] studied the characteristics of pollution in soils of Changchun City, and found that heavy metal pollution was serious, especially $\mathrm{Pb}$ and $\mathrm{Ni}$. These reports show that heavy metal pollution of soil in Changchun has a long history, and a good direction for development at present. At the same time, agricultural activities, mining, sewage irrigation, automobile exhaust emissions, and traffic dust have also been found to be the main factors affecting soil heavy metal pollution.

Ecological risk is the possibility of loss of system function caused by natural changes in the environment and changes in ecosystem composition and structure induced by human life activities. Guo P. et al. [32] studied the ecological risk of soil heavy metals in Changchun City, and found that the urban soil in Changchun City had mild ecological hazards, and $\mathrm{Pb}$, $\mathrm{Cu}$, and $\mathrm{Zn}$ posed slight ecological risks. The ecological risk of soil heavy metals is globally widespread. In the ecological assessment of soil heavy metals in Ramsar, Assam state, India, Nihal G. et al. [4] found that $\mathrm{Zn}$ and Mn pose ecological risks. Mirzaei M. et al. [14] found that the ecological risk of $\mathrm{Cd}$ was the highest in Chaharmahal and Bakhtiari Province of Iran. Through the study of soil heavy metals in the Changchun New Area, the ecological risk level of heavy metals in this area were found to be very strong and extremely strong. Therefore, heavy metal pollution in this area requires urgent attention. Early warning mechanisms should be strengthened for areas with slight, medium, and strong ecological risk. Risks should be identified as soon as possible, and effective measures should be taken to control soil pollution in a timely manner.

Health risk is the possibility of disease, disability, and health loss in the process of human life due to many factors of natural, social and human development. Heavy metals in the farmland soil of the study area have no non-carcinogenic and carcinogenic risks to adults, but pose non-carcinogenic risks to children, indicating that children are more vulnerable to heavy metals hazards, which is consistent with the results of Yang Z.P. et al. [31]. This may be because children have more opportunities to contact the soil and relatively low immunity. According to Yang Z.P. et al. [31], the same constituent of non-carcinogenic risks to adults risks may be related to differences in regions. The health risks of $\mathrm{As}$ and $\mathrm{Cr}$ in this area were relatively high, and oral intake is the most important pathway of exposure to heavy metals in urban surface soil, It is consistent with the evaluation results of Yang Z.P. et al. [31]. In the abovementioned studies, exposure to As is significantly lower than those of $\mathrm{Zn}, \mathrm{Cu}, \mathrm{Pb}$, etc., but the health risks are the largest. The health risks of heavy metals are related to the toxicity of heavy metals in addition to the exposure dose. Heavy metals As and $\mathrm{Hg}$ with high toxicity are more likely to have higher human health risks due to their small reference values. Considering that heavy metals entering the human body cannot be digested and absorbed completely, Li J.M. et al. [33], Li H. et al. [34], Wu H.J. et al. [35] and some other scholars have attempted to introduce bioavailability, and found that the carcinogenic risk and non-carcinogenic risk of heavy metals are significantly reduced for children. Such a consideration can provide more accurate assessments of the hazard risk of heavy metals. Therefore, this study overestimated the potential negative effects of heavy metals in soil to children, and further research is needed in the future. However, from the viewpoint of health, the prevention and control of soil pollution should not be slackened at this stage. Instead, the health risks of heavy metals in soil should be monitored more carefully and early warning systems should be strengthened.

\section{Conclusion}

(1) Heavy metals $\mathrm{Hg}, \mathrm{As}, \mathrm{Cr}, \mathrm{Cu}, \mathrm{Pb}, \mathrm{Cd}, \mathrm{Zn}$, and $\mathrm{Ni}$ in Longjia and Xiyingcheng of the Changchun New Area were all higher than the background values of Changchun soil, with $\mathrm{Hg}$ presenting the most prominent values. With an average value of $0.05 \mathrm{mg} \cdot \mathrm{kg}^{-1}$, $\mathrm{Hg}$ concentration exceeded the background value of Changchun soil by 2.78. The coefficient of variation of $\mathrm{Hg}$ in the Changchun New Area was $1.136 \mathrm{mg} \cdot \mathrm{kg}^{-1}$, suggesting the effects of human activities such as mining, mineral and waste accumulation, and transportation.

(2) $\mathrm{Hg}$ and Cd pollution were observed in the soil of the Changchun New Area, presenting ecological 
risks. The average geo-accumulation index of $\mathrm{Hg}$ was 0.425 , reflecting light to medium pollution level, and the risk index ranged from 41.56 to 806.33 , indicating moderate to very strong ecological risk.

(3) Children are more vulnerable to health threats posed by heavy metals, and oral intake is the main pathway of exposure to heavy metals. Toxic heavy metals As and $\mathrm{Cr}$ are more likely to cause human health risks, and their levels exceeded the EPA recommended value. Therefore, prevention measures need to be strengthened further.

\section{Acknowledgements}

This work was supported by the China Geological Survey Program ( No. DD20190340 ), which was established by China Geological Survey. During the research and writing process of this paper, Professor Hao Ziguo and senior engineer Bao Liran put forward valuable opinions and suggestions. Guidance and help from Professor Hanna Radecka, Professor Jerzy Radecki. The achievements and data of Chinese Academy of Geosciences, China University of Geosciences and China Geological Survey are cited in this paper. Thank you!

\section{Conflicts of Interest}

There is no conflict of interest in the article.

\section{References}

1. CAI K., DUAN Y.M., LUAN.W.L., Li Q., MA Y.C. Geochemical behavior of heavy metals $\mathrm{Pb}$ and $\mathrm{Hg}$ in the farmland soil of Hebei plain. Geology in China, 43 (4), 1420, 2016.

2. DIAMI S., KUSIN F., MADXIN Z. Potential ecological and human health risks of heavy metals in surface soils associated with iron ore mining in Pahang, Malaysia. Environmental Science and Pollution Research, 23 (20), 21086, 2016.

3. OBIORA S.C., CHUKWU A., DAVIES T.C. Heavy metals and health risk assessment of arable soils and food crops around $\mathrm{Pb}-\mathrm{Zn}$ mining localities in Enyigba, southeastern Nigeria. Journal of African Earth Sciences, 116, 182, 2016.

4. NIHAL G., SUDIP M., ANKIT S., RICHA A., LATHA R., ELDON R.R., MAHAVEER P.S. Speciation, contamination, ecological and human health risks assessment of heavy metals in soils dumped with municipal solid wastes. Chemosphere. 262, 128013, 2021.

5. ENKHXHIMEG B., TAKEHIKO M., KEISUKE F., SHIGEO N., SONOMDAGVA C., ALTANSUKH O., SOLONGO T., DAVAADORJ D.Ecological and Human Health Risk Assessment of Heavy Metal Pollution in the Soil of the Ger District in Ulaanbaatar, Mongolia. International Journal of Environmental Research and Public Health, 17 (4668), 4668, 2021.

6. WANG X.M., ZHANG R.L., WANG Y.M., LU X.W., ZHA F.G. Eco- toxicity Effect of Heavy Metals in Cropland
Soils Collected from the Vicinity of A Coal Mine in Huainan .Ecology and Environmental Sciences, 25 (5), 877, 2016.

7. JIANG H.H., CAI L.M., WEN H.H., HU G.C., CHEN L.G., LUO J. Anintegrated approach to quantifying ecological and human health risks from different sources of soil heavy metals. Science of the Total Environment, 701, 2020.

8. CAO Q., LIU B., REN Z., XIAO H., CHENG J., XUE W. Temporal Distribution Characteristic and Risk Analysis of Heavy Metals in Greenhouse Vegetable Soils. Polish Journal of Environmental Studies, 29 (3), 2071, 2020.

9. TIAN M.L., ZHONG X.M., ZHANG Y.X., YU Y.Y., PANG R. Concentrations and health risk assessment of heavy metal contents in soil and rice of mine contaminated areas. Environmental Science, 39 (6), 2919, 2018.

10. YANG Z.P., WANG L., ZHAI H., ZHAO J.J., LU W.X. Study on health risk of potentially toxic metals in near-surface urban dust in Changchun City.China Environmental Science, 35 (4), 1247, 2015.

11. LI H.J., TANG J., ZHANG N., LI Z.Y. Accumulation and Transformation of Soil Heavy Metals in Different Plants of Abandon Coal Mine.Hubei Agricultural Sciences, 53 (16),3784, 2014.

12. China Geological Survey. DD 2005-03 technical requirements for analysis of eco geochemical evaluation samples. Beijing: China Geological Survey, 2005.

13. TIAN S.Q., WANG S.J., BAI X.Y., ZHOU DD.Q., LUO G.J., YANG Y.J., HU Z.Y., LI C.J., DENG Y.H., QIAN L.Ecological security and health risk assessment of soil heavy metals on a village-level scale, based on different land use types. Environmental geochemistry and health, 42 (1), 3393, 2020.

14. MIRZAEI M., MAROFI S., SOLGI E., ABBASI M., KARIMI R., RIYAHI B., HAMID R. Ecological and health risks of soil and grape heavy metals in long-term fertilized vineyards (Chaharmahal and Bakhtiari province of Iran). Environmental Geochemistry and Health, 42 (1), 27, 2020.

15. ZUWEI W., ZENG X. Health Risks of Heavy Metals Uptake by Crops Grown in a Sewage Irrigation Area in China. Polish Journal of Environmental Studies, 24 (3), 1379, 2015.

16. DAI J.R., PANG X.G., SONG J.H., DONG J., HU X.P., LI X.P. A study of geochemical characteristics and ecological risk ofelements in soil of urban and suburban areas of Zibo City, Shandong Province. Geology in China, 45 (3), 617 , 2018.

17. ZHANG Y., GUI H., HUANG Y., YU H., LI J., WANG M. et al. Characteristics of Soil Heavy Metal Contents and its Source Analysis in Affected Areas of Luning Coal Mine in Huaibei Coalfield. Polish Journal of Environmental Studies, 30 (2), 1465, 2021.

18. ZHANG Y., GUI H., HUANG Y., YU H., LI J., WANG M. et al. Characteristics of Soil Heavy Metal Contents and its Source Analysis in Affected Areas of Luning Coal Mine in Huaibei Coalfield. Polish Journal of Environmental Studies, 30 (2), 1465, 2021.

19. LI Z., JIANG Y., ZU Y., MEI X., QIN L., LI B. Effects of Lime Application on Activities of Related Enzymes and Protein Expression of Saponin Metabolism of Panax notoginseng under Cadmium Stress. Polish Journal of Environmental Studies, 29 (6), 4199, 2020.

20. MIELCZAREK A., WOJCIECHOWICZ-ŻYTKO E.T.Bioaccumulation of Heavy Metals $(\mathrm{Zn}, \mathrm{Pb}, \mathrm{Cd})$ in Polistes nimphus (Christ, 1791) (Hymenoptera, 
Vespidae) Living on Contaminated Sites. Polish Journal of Environmental Studies, 29 (6), 4249, 2020.

21. Ministry of Environmental Protection of the People's Republic of China. Technical guidelines for risk assessment of contaminated: HJ 25.3- 2014. Beijing: China Environmental Science Press, 2014.

22. US EPA . Exposure factors handbook. Washington: National Center for Environmental Assessment, 2011.

23. ROLKA E., ŻOLNOWSKI A.C., SADOWSKA M.M. Assessment of Heavy Metal Content in Soils Adjacent to the DK16-Route in Olsztyn (North-Eastern Poland). Polish Journal of Environmental Studies, 29 (6), 4303, 2020.

24. BARTKOWIAK A., PIATEK M. Analysis of Heavy Metal Content in Soil Fertilised with Fresh and Granulated Digestate. Polish Journal of Environmental Studies, 29 (5), 3517, 2020.

25. GÁLUSOVÁ T., PIRŠELOVÁ B., RYBANSKÝ L., KRASYLENKO Y., MÉSZÁROS P., BLEHOVÁ A. et al. Plasticity of Soybean Stomatal Responses to Arsenic and Cadmium at the Whole Plant Level. Polish Journal of Environmental Studies, 29 (5), 3569, 2020.

26. USEPA. Regional screening level (RSL) for Chemical contaminants at superfund sites. Washington, DC: U.S.Environmental Protection Agency, 2013.

27. YIN Y.M., YUAN Z.W., HUANG T., CHENG S.G., ZHAO Z.L. Distribution characteristics and health risk assessment of heavy metals in a soil- rice system in an E- waste Dismantling area. Environmental Science, 39 (2), 916, 2018.

28. KORÇA B., DEMAKU S. Evaluating the Presence of Heavy Metals in the Vicinity of an Industrial
Complex. Polish Journal of Environmental Studies, 29 (5), 3643, 2020.

29. CHENG H.G., LI K., LI M., YANG K., LIU F., CHENG X.M. Geochemical background and baseline value of chemical elements in urban soil in China.Earth Science Frontiers, 21 (3), 265, 2014.

30. YALCIN I. E., OZAYIGIT I. I., DOGAN I., DEMIR G., YARCI C. Using the Turkish Red Pine Tree to Monitor Heavy Metal Pollution. Polish Journal of Environmental Studies, 29 (5), 3881, 2020.

31. YANG Z.P., WANG L., ZHAI H., ZHAO J.J., LU W.X. Study on health risk of potentially toxic metals in near-surface urban dust in Changchun City.China Environmental Science,35 (4), 1247, 2015.

32. GUO P., XIE Z.L.,LI J.,ZHOU L.F. Specificity of Heavy Metal Pollution and the Ecological Hazard in Urban Soils of Changchun City. Geographical Science, 25 (1), 108, 2005.

33. LI J.M., HOU H., WEI Y., XU YA.F., LI F.S. Bioaccessibility and health risk assessment of heavy metals in agricultural soil from Zhuzhou, China. Research of Environmental Sciences, 26 (10), 1139, 2013.

34. LI H., LI H.L., ZHU Y.E., LIU M., SHI W.Y. Health risk assessment based on bioavailability of heavy metals in contaminated sites. Journal of Earth Environment, 6 (1), 60, 2015.

35. WU H.J., FANG F.M., WU J.Y., YAO Y.R., WU M.H. Bioaccessibility and health risk of heavy metals at topsoil in primary schools in a coal mining city. Chinese Journal of Soil Science, 48 (5), 1247, 2017. 
